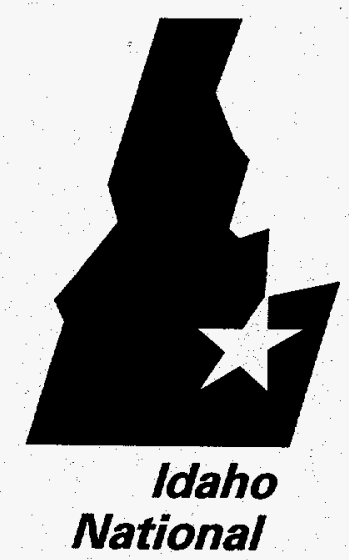

Engineering

Laboratory
INEL-95/0266

July 1995

\section{Safety Plan for the Cooperative Telerobotic Retrieval System Equipment Development Area}

T. J. Haney

DEC 211395

J. J. Jessmore 

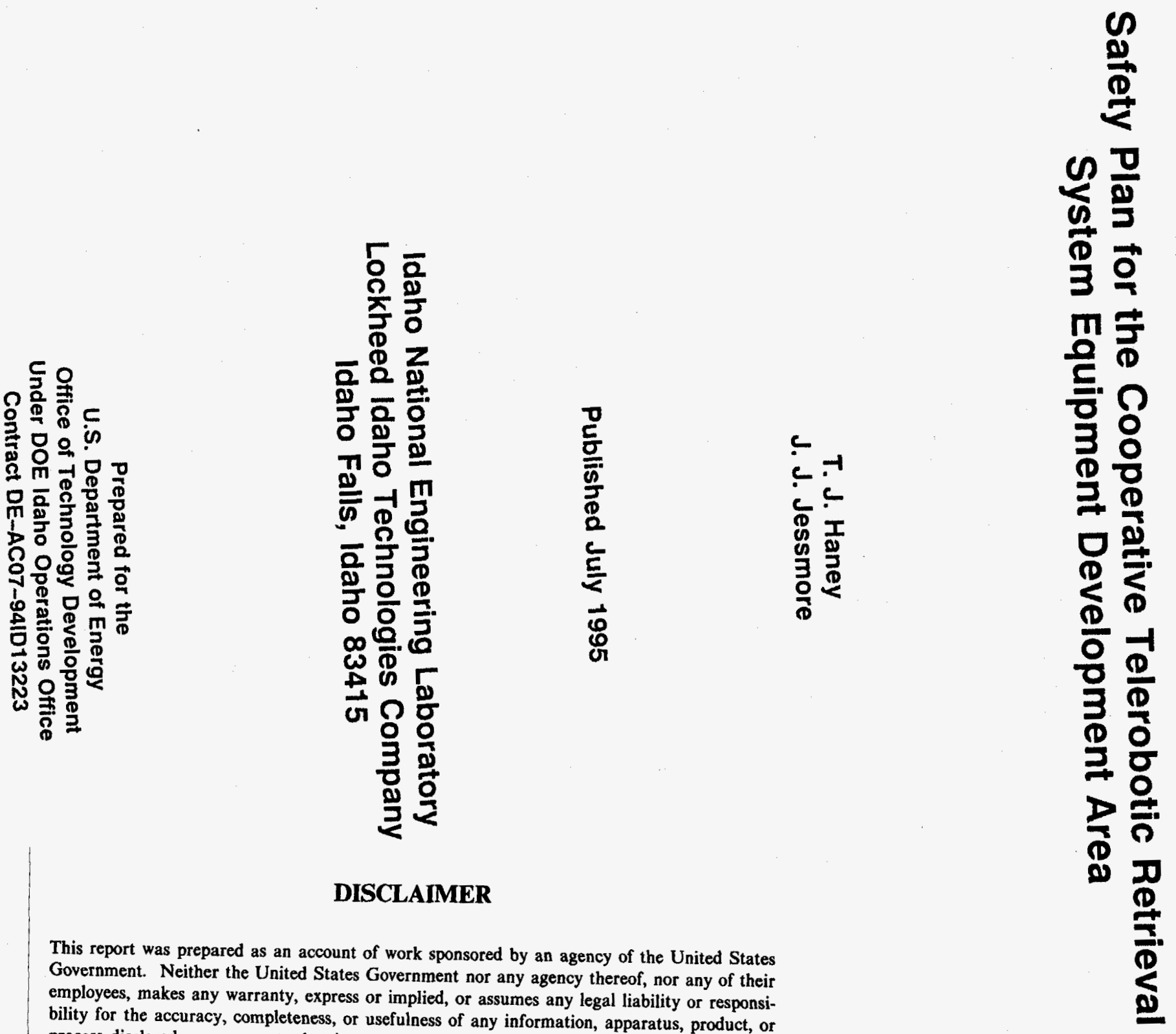

This report was prepared as an account of work sponsored by an agency of the United States Government. Neither the United States Government nor any agency thereof, nor any of their employees, makes any warranty, express or implied, or assumes any legal liability or responsibility for the accuracy, completeness, or usefulness of any information, apparatus, product, or process disclosed, or represents that its use would not infringe privately owned rights. Reference herein to any specific commercial product, process, or service by trade name, trademark manufacturer, or otherwise does not necessarily constitute or imply its endorsement, recommendation, or favoring by the United States Government or any agency thereof. The views and opinions of authors expressed herein do not necessarily state or reflect those of the United States Government or any agency thereof. 


\section{DISCLAMMER}

Portions of this document may be illegible in electronic image products. Images are produced from the best available original document. 


\section{Safety Plan for the Cooperative Telerobotic Retrieval System Equipment Development Area}

Approved by:

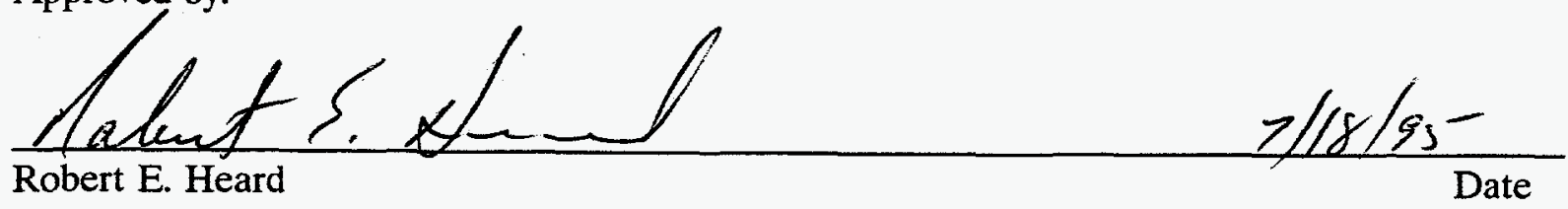

Deployment Program Manager

Reviewed by:

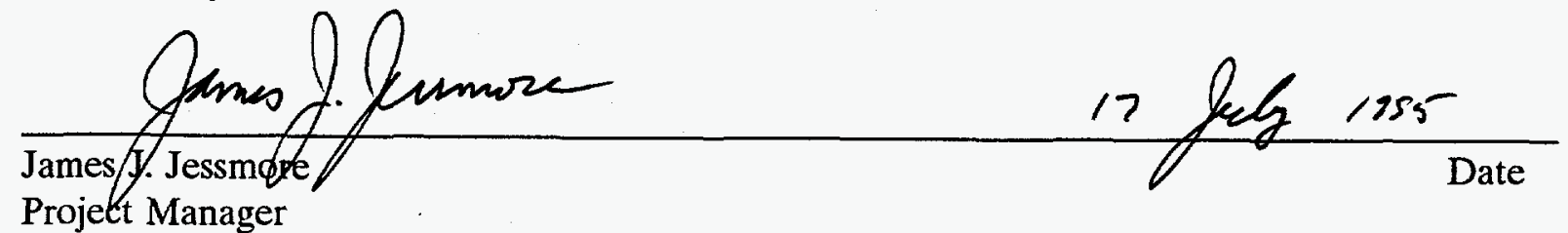

Projekt Manager

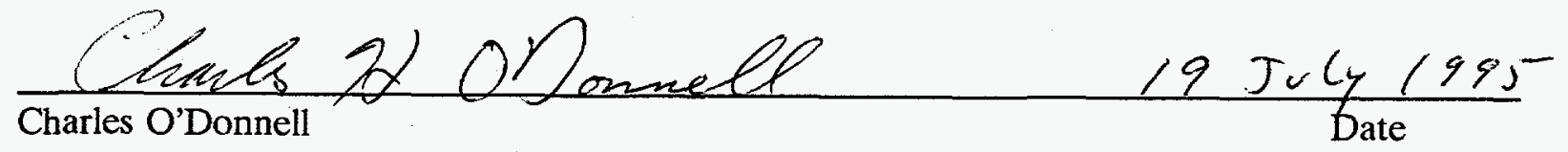

Safety Representative 


\section{CONTENTS}

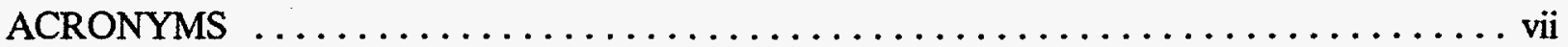

1. INTRODUCTION 1

1.1 Cooperative Telerobotic Retrieval System Description $\ldots \ldots \ldots \ldots \ldots \ldots \ldots$

2. PERSONNEL AND TASK SITE RESPONSIBILITIES

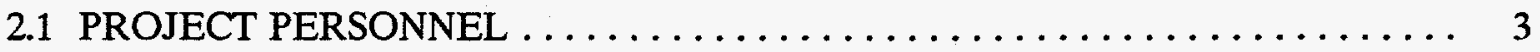

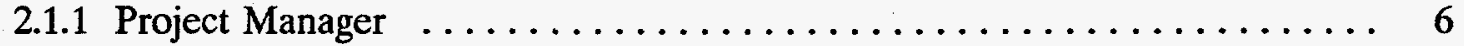

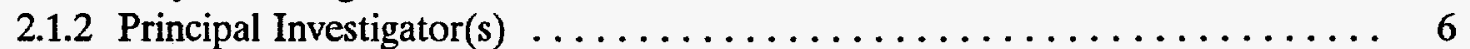

2.1.3 Lead Technician .......................... 6

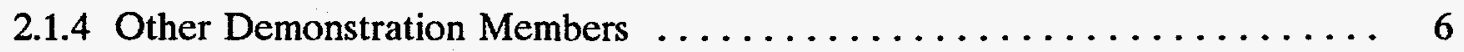

2.2 PROGRAM PERSONNEL $\ldots \ldots \ldots \ldots \ldots \ldots \ldots \ldots \ldots \ldots \ldots \ldots \ldots \ldots$

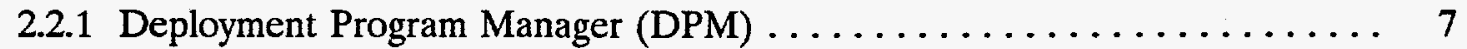

2.2.2 Environmental Restoration Technology Department Manager . . . . . . . 7

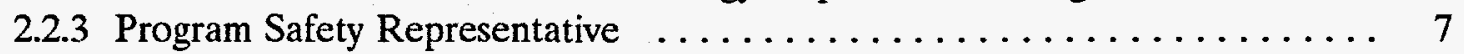

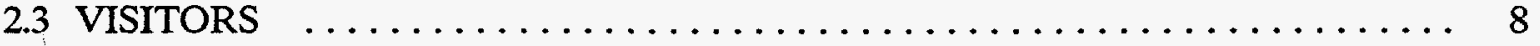

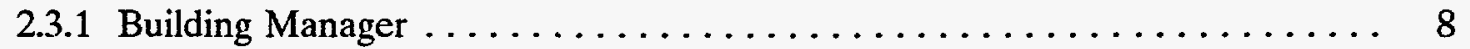

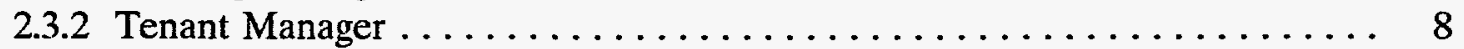

3. PERSONNEL TRAINING $\quad 8$

4. INJURIES ON THE TASK SITE $\quad 9$

5. SAFE WORK PRACTICES $\quad 10$

5.1 General Safe Work Practices . . . . . . . . . . . . . . . . . . . 10

6. EQUIPMENT DEVELOPMENT AREA CONTROL AND SECURITY 11

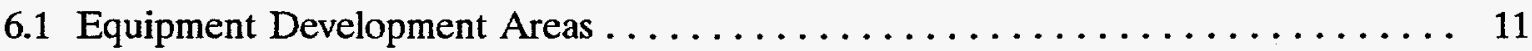

6.2 Console Restriction Area $\ldots \ldots \ldots \ldots \ldots \ldots \ldots \ldots \ldots \ldots \ldots \ldots \ldots \ldots$

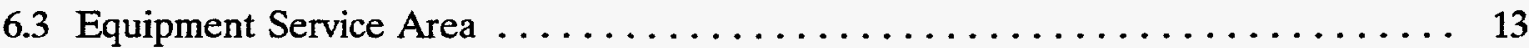

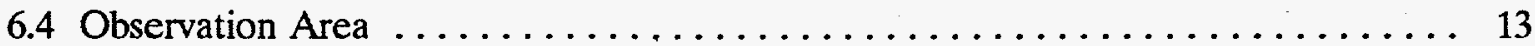

6.5 Primary Staging Area $\ldots \ldots \ldots \ldots \ldots \ldots \ldots \ldots \ldots \ldots \ldots \ldots$

7. HAZARD EVALUATION 14

7.1 Physical Hazards Evaluation, Control, and Monitoring $\ldots \ldots \ldots \ldots \ldots \ldots \ldots$

7.1 .1 Noise .............................. 15

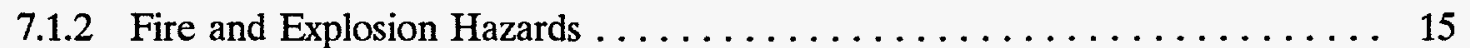

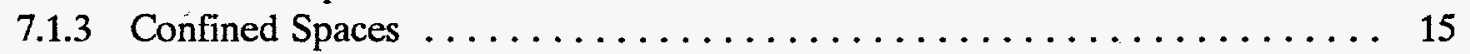

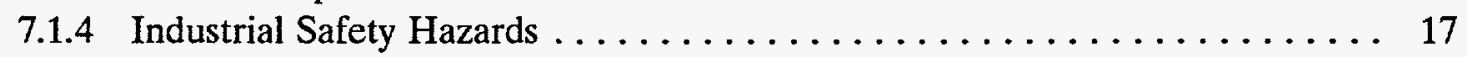

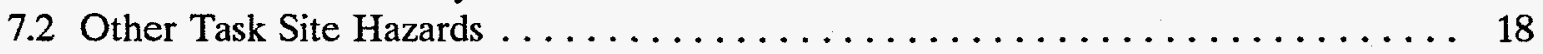

8. PERSONAL PROTECTIVE EQUIPMENT 19

9. EMERGENCY RESPONSE PLAN FOR TASK SITE 19 


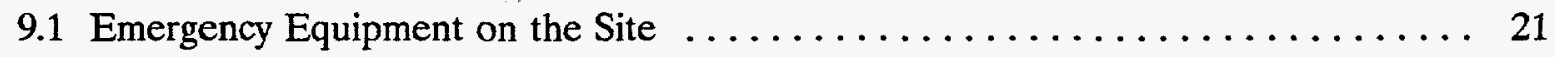

9.2 Telephone/Radio Contact Reference List for the Cooperative Telerobotic Retrieval System .................. 21

10. REFERENCES 21

Appendix A Safety Briefing Training Acknowledgment for CTR Project Areas

FIGURES

Figure 1. Suggested boundaries of the North Boulevard Annex Equipment Development

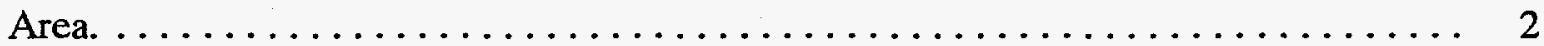

Figure 2. Suggested controlled areas at NBA. $\ldots \ldots \ldots \ldots \ldots \ldots \ldots \ldots \ldots, 4$

\section{TABLES}

1. Personnel and corresponding responsibilities $\ldots \ldots \ldots \ldots \ldots \ldots \ldots \ldots \ldots \ldots$

2. Required training for project personnel $\ldots \ldots \ldots \ldots \ldots \ldots \ldots \ldots \ldots \ldots$

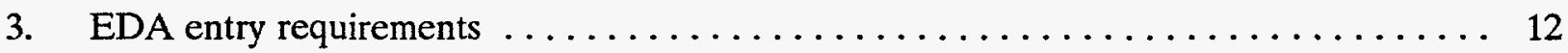

4. Task site activities and associated hazards $\ldots \ldots \ldots \ldots \ldots \ldots \ldots \ldots \ldots \ldots \ldots \ldots \ldots \ldots$

5. Hazardous materials present at the Cooperative Telerobotic Retrieval .......... 16

6. Emergency signals at building IF-613 (NBA) $\ldots \ldots \ldots \ldots \ldots \ldots \ldots \ldots \ldots \ldots \ldots \ldots \ldots$

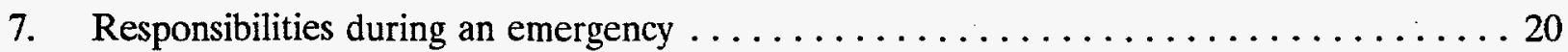

8. Telephone/Radio Contact Reference and Escort List for the Cooperative

Telerobotic Retrieval System ........................... 22 


\section{ACRONYMS}

\begin{tabular}{|c|c|}
\hline CRA & console restriction area \\
\hline CTR & Cooperative Telerobotic Retrieval \\
\hline DPM & Deployment Program Manager \\
\hline EDA & Equipment Development Area \\
\hline EPOC & emergency point of contact \\
\hline ES\&Q & Environmental Safety and Health \\
\hline ESA & equipment service area \\
\hline GFCI & ground fault circuit interrupted \\
\hline IFFD & Idaho Falls Fire Department \\
\hline $\mathrm{IH}$ & Industrial Hygienist \\
\hline LITCO & Lockheed Idaho Technologies Company \\
\hline LSFA TRU & Landfill Stabilization Focus Area Transuranic \\
\hline MSDS & material safety data sheet \\
\hline NBA & North Boulevard Annex \\
\hline NIOSH & National Institute for Occupational Safety and Health \\
\hline $\mathrm{OA}$ & Observation Area \\
\hline OSHA & Occupational Safety and Health Administration \\
\hline PI & Principal Investigator \\
\hline PM & Project Manager \\
\hline PPE & Personal Protective Equipment \\
\hline SGV & Self-guided Vehicle \\
\hline TIS & Training Inquiry System \\
\hline
\end{tabular}


WCC

Warning Communication Center 


\section{Safety Plan for the Cooperative Telerobotic Retrieval System Equipment Development Area}

\section{INTRODUCTION}

This plan establishes guidelines to minimize safety risks for the cooperative telerobotic retrieval project at the North Boulevard Annex (NBA). This plan has the dual purpose of minimizing safety risks to workers and visitors and of securing sensitive equipment from inadvertent damage by nonqualified personnel. This goal will be accomplished through physical control of work zones and through assigned responsibilities for project personnel. The scope of this plan is limited to establishing the working zone boundaries and entry requirements, and assigning responsibilities for project personnel. This plan does not supersede current safety organization responsibilities for the Landfill Stabilization Focus Area Transuranic (LSFA TRU) Arid outlined in the Environment, Safety, Health, and Quality Plan for the Buried Waste Integrated Demonstration Program; Tenant Manual; Idaho Falls Building Emergency Control Plan;; applicable Company Procedures; the attached Interface Agreement (Appendix A).

\subsection{Cooperative Telerobotic Retrieval System Description}

Under development in Idaho Falls, the Cooperative Telerobotic Retrieval (CTR) system occupies the northwest end of the NBA and the fenced area immediately behind the NBA (Figure 1). The CTR system is being designed and tested for performing site characterization, and remote handling, excavation, and retrieval of buried waste. A description of the CTR system, including a summary of health and safety issues, is included in the Cooperative Telerobotic Retrieval System Test Plan for Fiscal Year 1994. ${ }^{1}$ In brief, the system is comprised of an 80-ft wide dc servo-controlled gantry crane (gantry travel distance of approximately $48 \mathrm{ft}$ ), two servohydraulic manipulator systems, two independent telescoping mast assemblies for manipulator deployment, an independent 5-ton electric hoist, an electrical and electronics system, closed circuit cameras, a cable and hose management system, a vacuum system capable of soil sundering and vacuum transport, and tools such as a box handler, barrel handler, and magnet. Two operator stations with single screen operator interfaces (two mice and two force balls) allow controller supervision and/or direct control of 29 axes of motion with position feedback on each axis of motion.

The overall system is controlled through a modified commercial (Cimetrix, Inc.) control system. The controller provides servocontrol of the 29 axes of motion including a 3-D graphics simulation, which can be operated concurrently or separately from the system controller. The electrically powered crane and supporting equipment require approximately $70 \mathrm{~kW}$ of power. System design and software modifications are ongoing. Planned activities include excavation of two simulated waste sites or zones of environmental concern. The field demonstration is scheduled for the months of July and August 1995. 


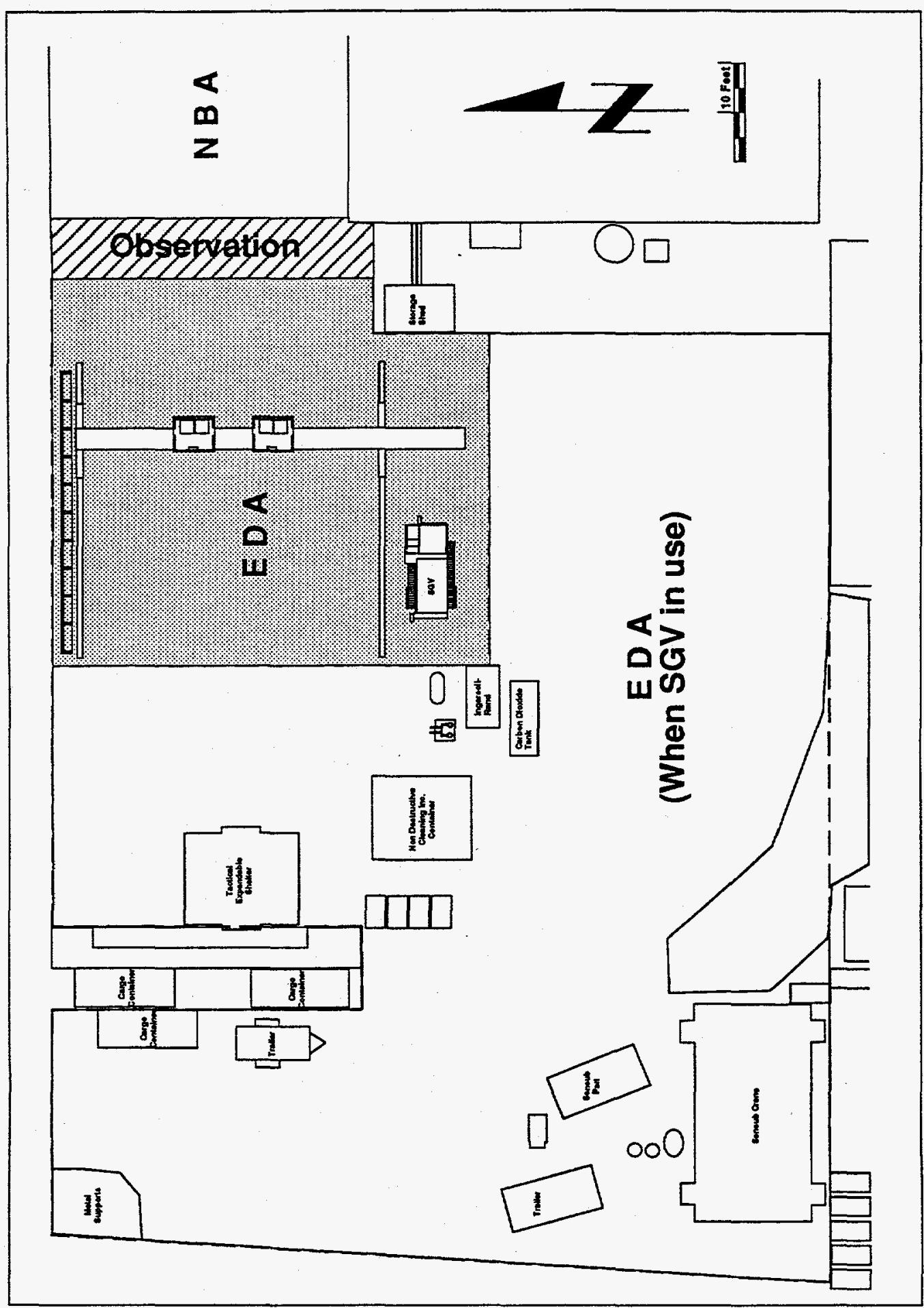

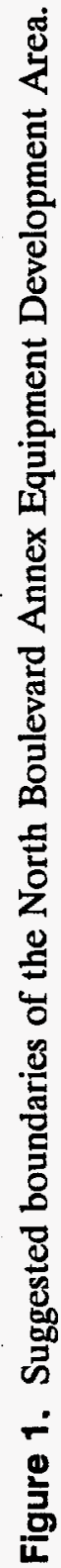




\section{PERSONNEL AND TASK SITE RESPONSIBILITIES}

The organizational structure for this task reflects the resources and expertise required to perform the task, while minimizing risks to worker health and safety. A list of PROJECT PERSONNEL directly involved with the CTR and supporting systems, PROGRAM PERSONNEL, and personnel classified as VISITORS along with corresponding responsibilities is presented in Table 1. Specified control zones which. will be referenced in the following sections are presented in Figure 2. The following subsections outline responsibilities for each designated personnel classification.

\subsection{PROJECT PERSONNEL}

PROJECT PERSONNEL $(\star)$ listed in Table 1 are trained in the safety requirements of the Equipment Development Area [(EDA), a full description of the EDA and its entry requirements are described in Section 6]. Training is to be documented by the Safety Briefing Training Acknowledgement (Appendix A). Qualified access to the EDA automatically enables access to all other identified areas.

PROJECT PERSONNEL work with the PIs to perform tasks outlined in work package documentation. These personnel are recognized as having the greatest degree of expertise required to conduct safe operations on the technologies being developed within the designated EDA (as per conditions outline in Section 6 of this documents). These people are responsible to enforce site control during day-to-day developmental operations and during testing, to escort nonworkers through designated EDA areas, and to bring potential safety issues to the attention of the DPM. PROJECT PERSONNEL are required to render equipment within the EDA safe by posting and enforcing clear administrative controls. During prolonged periods in which the equipment is left unattended, proper measures must be taken to secure the equipment from inadvertent activation (i.e. lock-out/tag-out procedures, barricading, depressurizing, etc.). The $\mathrm{PI}(\mathrm{s})$ or designated alternate(s) shall be responsible to perform regular inspections of the EDA to ensure compliance with these requirements. The PM and DPM shall also perform routine walkthrough inspections to ensure compliance. Only PROJECT PERSONNEL may enter the Console Restriction Area (CRA).

PROJECT PERSONNEL escort responsibilities include, but are not limited to: responsibility for ensuring that NON-PROJECT PERSONNEL entering the EDA and/or Equipment Service Area (ESA) are briefed on the daily hazards, emergency routes and actions, access limitations, and insuring that sign-in and sign-out procedures are met. These procedures require that, NONPROJECT PERSONNEL entering the EDA or ESA shall record in the EDA logbook required personal information, and time entering and exiting the area. The identity of the escorting PROJECT REP must be notated by signature next to each person being escorted. The number of persons being escorted by one PROJECT REP is limited to 15. 


\section{IF 613 North Boulevard Annex}

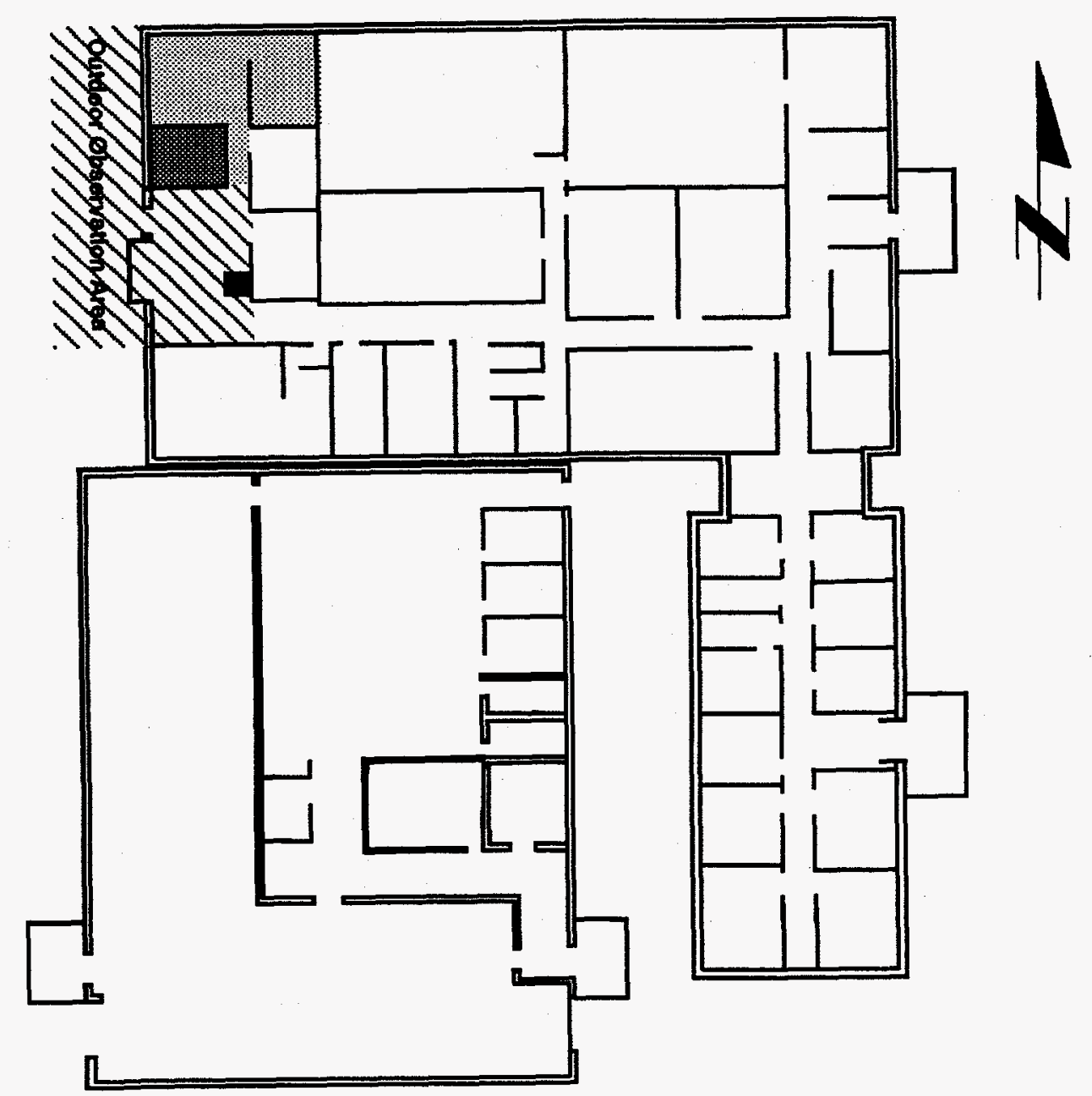

Console Restriction Area

Equipment Service Area

Observation Area (during Demonstration only)

\section{Primary Staging Area}

Figure 2. Suggested controlled areas at NBA. 
Table 1. Personnel and corresponding responsibilities.

\begin{tabular}{|c|c|c|}
\hline Responsibility & Personnel & Telephone number \\
\hline $\begin{array}{l}\text { Environmental Restoration Technology } \\
\text { Dept. Mgr. }\end{array}$ & K. M. Kostelnik & $526-9642$ \\
\hline LSFA TRU Arid Lead & $\bullet$ D. F. Nickelson & $526-9061$ \\
\hline Safety Representative & C. H. O’Donnell & $526-0722$ \\
\hline ESH\&Q Representative & $\oplus$ L. C. Rounds & $526-0063$ \\
\hline Deployment Program Manager (DPM) & $\star$ R. E. Heard & $526-7379$ \\
\hline Project Manager (PM) & $\star$ J. J. Jessmore & $526-7558$ \\
\hline Principal Investigator/Mechanical Engineer & $\star$ K. M. Croft & $526-8276$ \\
\hline \multicolumn{3}{|l|}{ Robotics Organization } \\
\hline & $\star$ R. Theobald & $526-0774$ \\
\hline Mechanical Engineer & $\star$ R. A. Hyde & $526-0741$ \\
\hline Electrical Engineer & $\star$ S. M. Allen & $526-8215$ \\
\hline Software Engineer & $\star$ W. F. Boyer & $525-5591$ \\
\hline Mechanical Engineer & $\star$ S. Walker & $526-8815$ \\
\hline Lead Technician & $\star$ L. J. Hanson & $526-4997$ \\
\hline Deployment Coordinator & $\star$ L. R. Watson & $526-2232$ \\
\hline $\begin{array}{l}\text { Digface Sensor Reps. } \\
\text { VOC Sensor } \\
\text { Imaging Infrared Interferometer } \\
\text { High Impulse Radar } \\
\text { Data Acquisition } \\
\text { WP Manager }\end{array}$ & $\begin{array}{l}\star \text { J. K. Partin } \\
\star \text { G. A. Moore } \\
\star \text { W. Lechelt } \\
\star \text { J. M. Svoboda } \\
\star \text { L. G. Roybal }\end{array}$ & $\begin{array}{l}526-2822 \\
526-9587 \\
\text { NA } \\
526-0671 \\
526-5744\end{array}$ \\
\hline $\begin{array}{l}\text { SGV Representatives } \\
\text { Project Manager } \\
\text { PI } \\
\text { RAHCO Representatives } \\
\text { SPAR Representatives } \\
\text { RSI Representatives }\end{array}$ & $\begin{array}{l}\star \text { B. M. Gardner } \\
\star \text { P. M. Rice } \\
\star \text { TBD } \\
\star \text { TBD } \\
\star \text { TBD }\end{array}$ & $\begin{array}{l}526-0409 \\
526-2884\end{array}$ \\
\hline Building Manager & ○ S. L. Herndon & $526-5509$ \\
\hline $\begin{array}{l}\text { Tenant Manager } \\
\text { - PROGRAM REPRESENTATIVE (REPs) } \\
\text { - VISITORS } \\
\star \text { - PROJECT REPs }\end{array}$ & ○ B. M. Wilding & $526-8160$ \\
\hline
\end{tabular}


The following subsections identify some of the key PROJECT REPs and their specific responsibilities.

\subsubsection{Project Manager}

The Project Manager (PM) has ultimate responsibility for the successful completion of assigned LSFA TRU Arid projects. The PM provides technical coordination and interfaces with the DPM, LSFA TRU Arid Lead, and the DOE-ID Field Office. The PM ensures that all activities are conducted in accordance with DOE, EPA, and State of Idaho requirements and agreements; monitors and approves project budgets and schedules; ensures the availability of necessary personnel, equipment, subcontractors, and services; provides direction for the development of tasks, evaluation of findings, development of conclusions and recommendations, and production of reports.

\subsubsection{Principal Investigator(s)}

The Principal Investigator(s) (PIs) share responsibility for the technical quality and successful completion of the project. The PIs provide coordination and direction for the development of tasks, evaluation of findings, and development of conclusions and recommendations. As senior engineer, the PIs act as a focal point for system developmental decision. PIs are responsible for providing and obtaining training for PROJECT PERSONNEL specific to the safe operation of their technology before final development and subsequent field testing. The PI, and/or designated team members, are responsible for effectively communicating equipment status changes to all personnel in the EDA (examples: energizing the crane, engaging the hydraulic power unit(s), movement of the crane, hoist, or Schilling arms, ect.)

\subsubsection{Lead Technician}

The lead technician performs installations, maintenance, trouble shooting, ect. functions on the CTR system. He is routinely actively working in the EDA at the direction of the PI or lead engineers. Under certain circumstances, the lead technician may enlist the support of other technicians. In such instances, it is the responsibility of the lead tech and the PI to assure that these personnel have received training where required (example: scissor lift operation, harness training, etc.), and that information be provided to the PM for records.

\subsubsection{Other Demonstration Members}

Other demonstration project members (identified in Table 1) include subcontractor and LMIT personnel involved with the Self-Guided Vehicle (SGV), Digface Sensor Team. These team members include representatives from RAHCO International, SPAR Aerospace Limited, and RSI Research Limited, Concept Engineering Group, and Pacific Northwest Laboratories. All requirements for EDA entry identified for PROJECT REPs apply to other demonstration project members, and their support technicians while maintaining their specified technology. Persons identified in Table 1 under heading for Digface Sensor, and SGV, are responsible for briefing any of their support personnel as to the hazards of entering the EDA (reference Hazard Communications Board located in the Primary Briefing Area). These persons are also responsible for informing operators of all other energized technologies of their entry into the EDA to assure that equipment status changes will be effectively communicated to all personnel in the area. Likewise, these persons, or designees, must inform other technology team members of status changes of their specific technologies. 


\subsection{PROGRAM PERSONNEL}

PROGRAM PERSONNEL are those persons familiar with the systems, but not knowledgeable of their developmental and/or operational requirements. These personnel are allowed unescorted access to the ESA, and OAs, but are require to comply with VISITOR escort procedures to enter the EDA. PROGRAM PERSONNEL may not enter the CRA.

The following subsections identify some of the key PROGRAM REPs and their specific responsibilities.

\subsubsection{Deployment Program Manager (DPM)}

The DPM is responsible for coordinating all INEL-sponsored field test activities including monitoring technical progress, cost, and schedule performance of all participating organizations in accordance with established Technical Task Plans (TTPs). The DPM reports to the LSFA TRU Arid Lead on programmatic progress, makes recommendations affecting budgets and schedules, and suggests corrective actions as appropriate. The DPM is responsible for project risk assessment and contingency planning identifying critical systems, subsystems, and other areas requiring focused analysis and resolution. Risks appear in technical, schedule and cost, quality, environmental, health, safety, regulatory, and utility areas. The DPM is responsible for clearly delegating authority and establishing performance accountability.

The DPM is additionally responsible for all required activities at the NBA test pit. The necessary infrastructure will be provided to ensure safe and successful field tests at the test pit. This infrastructure will be developed through internal means or by subcontract. It is the responsibility of every person or organization conducting testing and demonstration at either the INEL cold test pit or NBA test pit to know and comply

with all established requirements.

\subsubsection{Environmental Restoration Technology Department Manager}

The Environmental Restoration Technology Department Manager functions as the focal point for all contacts and correspondence relative to INEL activities. The Environmental Restoration Technology Department Manager is responsible for ensuring that the Office of Technology Department programmatic objectives are achieved by recommending technologies and projects to DOE-HQ through DOE-ID. The Environmental Restoration Technology Department Manager oversees technology evaluations and programmatic direction with the assistance of the Technical Support Group and Technical and Academic Review Group. The Environmental Restoration Technology Department Manager also functions as the principal interface with other Office of Technology Department-sponsored programs.

\subsubsection{Program Safety Representative}

The safety representative observes site activity on a weekly walk-through and assesses compliance with LITCO procedures, advises the personnel on required safety equipment, and recommends solutions to industrial safety issues that may arise. The safety representative may have other duties at the task site as specified in Company procedures and manuals. 


\subsection{VISITORS}

All persons not previously identified shall be considered VISITORS when entering regions of the NBA occupied by the CTR project. Representatives of DOE, State and Federal regulatory bodies, and other Lockheed Martin Idaho Technologies (LMIT) employees, etc., shall be considered VISITORS. No visitors may proceed into an EDA (with systems deenergized), ESA, or OA, without receiving a daily safety briefing, donning required safety gear, and contacting a key project member for escort purposes where required. Such personnel are required to sign the EDA visitors logbook located at the primary staging area. VISITORS may not enter the CRA.

The following subsections identify some of the key.VISITORS and their specific responsibilities.

\subsubsection{Building Manager}

Building managers have total responsibility for assigned facilities and take what ever initiative appropriate to fulfill these responsibilities. The building manager responsibilities are outlined in the LITCO Management Policies Manual, (In Transition) Section 11 and in the Interface Agreement Between North Boulevard Tenant Manager and the Buried Waste Integrated Demonstration Coordinator. Generally, the building manager is responsible for the safety of personnel and the safe completion of all project activities conducted within their area. Therefore, the building manager (or their representative) will be kept informed of all activities performed in the area. Where applicable, the building manager (or representative) and the project shall agree upon a schedule for reporting task progress and plans for work. The building manager (or representative) may serve as an advisor to task operations personnel with regard to the area operations.

\subsubsection{Tenant Manager}

The general responsibilities of the tenant manager are described in the LITCO Management Policies Manual, (In Transition), Section 11 and in the Interface Agreement Between North Boulevard Tenant Manager and the Buried Waste Integrated Demonstration Coordinator.. The tenant manager is responsible for maintaining their assigned facility, and must be cognizant of work being conducted in the facility. The facility tenant manager may be required to sign safe work permits that govern work performed at the facility.

\section{PERSONNEL TRAINING}

All PROJECT PERSONNEL will receive training as specified by the LITCO Company Procedures Manual. Table 2 summarizes training requirements for PROJECT PERSONNEL. Specific training requirements for each worker may vary depending on the hazards associated with the job assignment. Proof of completion of all required training courses (including refresher training) must be maintained on the site at all times. Examples of acceptable written training documents include a certificate issued by the institution where the training was received and/or a copy of an individual's Training Inquiry System (TIS) printout demonstrating completion of training.

A project safety orientation will be attended by the project team members. The orientation will consist of a review of this plan and attachments, with time for discussion and questions. At this time, personnel training will be checked and verified to be current and complete for all required training shown

in Table 2. Upon completing the safety orientation, personnel will sign the training acknowledgment form (Appendix S) to indicate that they have received the briefing and understand the plan. During the 
briefing, tasks are to be outlined; hazards, hazard controls, and work areas identified; and personal protective equipment (PPE) requirements discussed. After the completion of this briefing, worker's health and safety questions concerning tasks will be addressed. In addition, while equipment is energized, a daily safety briefing will identify operations and associated hazards for the day. As part of the General Equipment Operations training, personnel must be shown and understand how to operate the emergency shutoff mechanism to the crane, support equipment, and all ancillary tools.

\section{INJURIES ON THE TASK SITE}

In the event of an on-site injury or illness, the worker(s) or visitor(s) shall be transported to the nearest medical facility for evaluation, with as much information as possible regarding the suspected cause of injury or illness. As much of the following information as is available will accompany the individual to the medical facility, including:

- Name, job title, work location, and supervisor's name and phone number

- $\quad$ Substances or physical agents (known or suspected); material safety data sheet (MSDS) if applicable

- Nature of accident causing injury or illness

- Date of employee's first exposure to the substance or physical agent (if known)

- Locations, dates, and results of exposure monitoring (if known).

Further medical evaluation will be in accordance with the symptoms, hazard involved, exposure level, and specific medical surveillance requirements. No substance-specific medical surveillance requirements apply to personnel working at the task site.

Table 2. Required training for project personnel.

\begin{tabular}{lccc}
\hline \multicolumn{1}{c}{ Personnel Classification } & PROJECT & PROGRAM & VISITORS \\
\hline \multicolumn{1}{c}{ Topic } & Required & Required & Required \\
\hline Safety orientation $^{\prime}$ & $\mathrm{X}$ & $\mathrm{X}$ & $\mathrm{X}$ \\
Hazard communication $^{\mathrm{a}}$ & $\mathrm{X}$ & $\mathrm{X}$ & $\mathrm{X}$ \\
Site control and warning devices $^{\mathrm{a}}$ & $\mathrm{X}$ & $\mathrm{X}$ & $\mathrm{X}$ \\
Emergency action plan for task site $^{\mathrm{a}}$ & $\mathrm{X}$ & $\mathrm{X}$ & $\mathrm{X}$ \\
General equipment operations $^{\text {Hearing conservation }}$ & $\mathrm{X}$ & - & - \\
\hline \hline
\end{tabular}

a. Will be included in safety briefing.

b. As determined by safety representative. 


\section{SAFE WORK PRACTICES}

\subsection{General Safe Work Practices}

The following are general safe work practices that will be followed at the task site:

1. Personnel shall wear a hardhat and safety eyewear in the EDA; safety eyewear will be worn in other designated areas when performing work requiring eye protection (drilling, hammering, etc.)

2. Be alert for dangerous situations, strong or irritating odors, and airborne dusts or vapors. Report all potentially dangerous situations to the DPM, PIs, and Tenant Manager.

3. Prevent releases of hazardous materials, if any are present at the task site. If a spill occurs, contain it (if possible) and report it to the DPM and facility representative. Steps must then be taken to clean it up in accordance with the appropriate procedure. Guidelines for spill cleanup in Appendix III of the LITCO Company Procedures Manual, Section 11.6 are summarized in Section 10 of this plan.

4. Keep all ignition sources at least $50 \mathrm{ft}$ from explosive or flammable environments and use nonsparking, explosion-proof equipment if advised to do so by a safety professional.

5. Be familiar with the physical characteristics of the task site, including, but not limited to:

a. Wind direction

b. Location of fellow workers, equipment, and vehicles

c. Communications at the task site and with other nearby facilities

d. Major roads and means of access to and from the task site

e. Nearest water sources and fire fighting equipment

f. Warning devices, alarms, and emergency phone numbers

g. Capabilities and location of nearest emergency assistance.

6. In the event of a facility evacuation, all technologies will be disabled by their respective operators prior to leaving the facility (ie. use of Emergency-Stop mechanisms, or direct power interruption). 


\section{EQUIPMENT DEVELOPMENT AREA CONTROL AND SECURITY}

The following subsections identify the technology specific EDAs, the CRA, ESA, OAs, and their associated signs and barriers. Figures 1 and 2 depict areas within the NBA complex designated to the CTR project, with suggested work area delineations (the size and location of these areas are alterable by PROJECT PERSONNEL). The five general areas are the

1. Primary staging area

2. Equipment development areas (EDA)

3. Console restriction area (CRA)

4. Equipment service area (ESA)

5. Observation Area (OA)

Entry into designated areas is controlled through the barriers, signs, and other measures described in this section. VISITORS, such as inspectors, may be admitted into certain work areas provided they are on official business, escorted by a project member, have demonstrated compliance with the training requirements in Section 3 , and have signed the training acknowledgment form and the EDA visitors logbook. All personnel classifications entering an EDA, including VISITORS, are responsible for understanding and complying with requirements of the EDA. If unsafe conditions develop, all personnel are authorized to stop work and notify the DPM or designated alternate of the unsafe condition. PROJECT PERSONNEL have authority to take or direct actions to ensure that people (and equipment) are protected. In the event of an emergency, evacuation through controlled work areas is authorized if recommended IF-613 evacuation routes are blocked or appear unsafe.

\subsection{Equipment Development Areas}

The EDA encompasses the gantry crane and associated operations areas. This EDA was established to prevent unauthorized access to potentially hazardous operations and to allow prototype development to proceed in a timely manner. The approximate outside EDA dimensions are $150 \times 150 \mathrm{ft}$; however, the EDA boundary as defined by fencing and signs may be modified by PROJECT PERSONNEL to include new operations such as SGV operations and the 20 -ft overhang outside the clear span envelope. To reduce or eliminate such a zone, the DPM, PIs, and PM (or designated alternates) must be involved in the decision. Facility tenants other than project personnel will be familiarized with the established boundaries and postings of the EDA and comply with VISITOR restrictions. The EDA perimeter will be fenced with orange construction fencing and identified with standard Caution Signs stating EQUIPMENT DEVELOPMENT AREA - ENTRY BY AUTHORIZED EMPLOYEES ONLY. Additional information on the signs may include the PPE required for entry. The signs may be hung on four sides of the EDA including one near the designated entry point on the east EDA boundary. Hard hats and safety glasses are the minimal PPE required for EDA entry. Additional requirements will be determined by the safety representative or certified safety professional. 
Generally, the gantry crane and related equipment in the EDA will be isolated from power sources and in a zero energy state in compliance with applicable lock-out tag-put procedures before work being performed. However, troubleshooting, repair, modification, and redesign are typical prototype development activities, some of which involve working on energized equipment. When equipment is energized, only the PROJECT PERSONNEL listed in Table 1 and other demonstration project members are allowed to enter the EDA.

Equipment operators (if required to activate equipment) must be in contact with workers in the EDA at all times via various means such as 2-way radio, video, line-of-sight, or third person relay. If such contact is impossible, the control console must be secure to disallow equipment from being engaged. Authorized operation of the prototype equipment while personnel are inside the EDA requires the operating speed be limited to $250 \mathrm{~mm} / \mathrm{sec}$ (approx. 10-inches/sec) or less, per ANSI Standard for Robotics Operations (ANSI/RIA R15.06-1992, page 15, Annex A). When equipment in the EDA is energized, an additional sign marked DANGER - EQUIPMENT ENERGIZED will be placed by the PIs, or designated alternate, in a highly visible location near the EDA and ESA access points. When project personnel are absent and equipment is energized, the sign shall be placed by the PIs or designated alternate across the EDA access point. An announcement will be made, a minimum of 2-minutes prior to energizing the system, over a public announcement system before energizing the system.

When equipment is deenergized and if all applicable requirements for securing the equipment are met, PROGRAM and VISITOR personnel may enter the EDA. During testing activities, or at any time when equipment is energized, only PROJECT PERSONNEL may enter the EDA. Table 3 summarizes the entry requirements for personnel authorized to enter the EDA.

Table 3. EDA entry requirements.

\begin{tabular}{|c|c|c|c|c|}
\hline Classification & $\begin{array}{l}\text { Enter EDA if } \\
\text { equipment } \\
\text { deenergized }^{a}\end{array}$ & Required for entry ${ }^{b}$ & $\begin{array}{l}\text { Enter } \\
\text { EDA with } \\
\text { equipment } \\
\text { energized? }\end{array}$ & Required for entry ${ }^{b}$ \\
\hline $\begin{array}{l}\text { Project } \\
\text { personnel }\end{array}$ & Yes & $\begin{array}{l}\text { Hard hat, safety } \\
\text { eyewear }\end{array}$ & Yes & $\begin{array}{l}\text { Hard hat, safety } \\
\text { eyewear }\end{array}$ \\
\hline $\begin{array}{l}\text { Other } \\
\text { demonstration } \\
\text { project } \\
\text { member }\end{array}$ & Yes & $\begin{array}{l}\text { Hard hat, safety } \\
\text { eyewear, }\end{array}$ & Yes & $\begin{array}{l}\text { Escort, hard hat, } \\
\text { safety eyewear }\end{array}$ \\
\hline $\begin{array}{l}\text { Visitor and } \\
\text { program } \\
\text { personnel }\end{array}$ & Yes & $\begin{array}{l}\text { Hard hat, safety } \\
\text { eyewear, escort, } \\
\text { receive safety briefing, } \\
\text { and sign EDA visitors } \\
\text { log, verify training. }\end{array}$ & & $\begin{array}{l}\text { EDA entry not } \\
\text { allowed when } \\
\text { equipment is } \\
\text { energized. }\end{array}$ \\
\hline
\end{tabular}




\subsection{Console Restriction Area}

The CRA includes the moveable wooden platform supporting the prototype control center, the associated software development area, and digface and soil vacuum data acquisition hardware. Console equipment operators direct the movement of the gantry crane and ancillary hardware. Access to the CRA is limited to PROJECT PERSONNEL to safeguard equipment. While neither a sign-in sheet nor PPE are necessary for entry into the CRA, nonproject personnel are denied access. During the demonstration, the nearby OA area allows nonworkers and visitors a view of the console operation. The CRA will be controlled with the use of a theater-type rope and Caution Signs stating CONSOLE RESTRICTION AREA - ACCESS BY AUTHORIZED PERSONNEL ONLY. Because the CRA is mobile, its boundaries may be modified by key project personnel to include new locations. To reduce or eliminate the CRA, the DPM, PIs, and PM (or designated alternates) must be involved in the decision.

\subsection{Equipment Service Area}

Access to the ESA is controlled to protect non-project employees from potential harm to themselves and to sensitive project equipment. The ESA boundary will be designated with a standardized Caution Sign stating EQUIPMENT SERVICE AREA - WORK BY AUTHORIZED EMPLOYEES ONLY. The boundary of the ESA may be reduced by PROJECT PERSONNEL, with required approval, to expand the OA to accommodate viewers during the field test. The suggested ESA boundary shown in Figure 2 will be present during prefield test operations. Only PROJECT PERSONNEL and personnel escorted by project personnel may enter the ESA. Other personnel (e.g., custodian) that must enter the area routinely may be granted unescorted access on a case-by-case basis, but must be made aware of potential hazards in the ESA. If equipment in the ESA must remain energized for testing and/or troubleshooting and an unprotected exposure presents a potential personnel hazard, the ESA must be marked DANGER - EQUIPMENT ENERGIZED if the project personnel leave the immediate area.

\subsection{Observation Area}

The OA is the area outside the clearly marked EDA, CRA, and ESA. There are no entry requirements for the $O A$ other than those required for entry into building IF-613. Note that the OA only exists during demonstration activities and access is restricted at all other times. At times other than during a demonstration, only PROJECT PERSONNEL or personnel escorted by project personnel may enter. During demonstrations, people in the OA may wish to wear safety glasses. Any requested PPE will be made available to people in the OA. 


\subsection{Primary Staging Area}

The primary staging area is located inside the NBA near the OA access (Figure 2). All personnel have access to the primary staging area, which serves to centralize task site support materials including

- Safety manuals, procedure documents, MSDSs, etc.

- Emergency phone numbers, exit routes, alarm signals

- Daily hazards board

- Visitor sign-in and training acknowledgment forms

- First aid supplies, eyewash.

\section{HAZARD EVALUATION}

Project personnel may be exposed to safety hazards while working with the CTR system, especially while in the EDA. Table 4 summarizes each task and the associated hazards. MSDSs for the materials stored or used at the NBA are posted in the primary staging area (Figure 2).

Hazardous substances related to CTR activities (see Table 5) that may be present at the task site include:

- Diesel fuel may be present in the SGV and/or generator. Diesel exhaust is considered by the National Institute for Occupational Safety and Health (NIOSH) to be a potential occupational carcinogen; however, the location of diesel driven equipment will likely be remote (approximately $50 \mathrm{ft}$ ) from the $\mathrm{OA}$ and the exposure risk to the diesel exhaust vapors is expected to be minimal. The safety representative and/or the industrial hygienist (IH) will determine monitoring requirements. An MSDS for diesel fuel will be placed in the Primary Staging Area.

- Aviation Hydraulic Fluid will be present in a closed system; under normal conditions there is no exposure. Leaks or ruptures could create inhalable mists and potential fire hazards. Skin contact should be avoided. An MSDS for the hydraulic fluid will be placed in the Primary Staging Area. 
Table 4. Task site activities and associated hazards.

\begin{tabular}{ll}
\hline Activity or task & Associated hazards \\
\hline Mechanical & Cuts, bruises, particles in eyes, noise \\
Electrical/pressurized & Electrical shock, burns, acceleration, noise \\
Physical/material handling & Strains, sprains, heat/cold stress \\
Working at heights & Falling, dropped objects \\
Crane/SGV & Mass, gravity, height \\
\hline
\end{tabular}

\subsection{Physical Hazards Evaluation, Control, and Monitoring}

The physical hazards present at the task site, and the methods that will be used to monitor and control them, are described in the following paragraphs.

\subsubsection{Noise}

Personnel working at the task site may be exposed to noise levels in excess of $85 \mathrm{db}(\mathrm{A})$ from heavy equipment, portable generators, or vacuum blowers. Personnel working on jobs that are noisy will be required to wear hearing protection until the noise levels have been evaluated by certified safety representatives.

\subsubsection{Fire and Explosion Hazards}

Explosion and fire hazards at the site may include flammable liquids such as fuels or solvents. Safe storage, handling, and use, including container labeling, will be used for all flammable materials used at the site. Flammable and combustible liquids will be handled per LITCO Company Procedure 6.7, "Storage and Use of Flammable and Combustible Liquids."

\subsubsection{Confined Spaces}

A pit will be excavated at the site. There will be no human entry, but it will be filled with mock waste drums and soil for the FY-95 Integrated Field Test. The pit will be posted with the required danger sign per the LITCO Company Procedures Manual, Section 11.3, Appendix I. If the pit is excavated to greater than $0.9 \mathrm{~m}(3 \mathrm{ft})$ and human entry becomes necessary for equipment retrieval or other reasons, an $\mathrm{IH}$ or safety engineer will first evaluate the pit per the LITCO Company Procedures Manual, Section 11.3. 
Table 5. Hazardous materials present at the Cooperative Telerobotic Retrieval.

\begin{tabular}{|c|c|c|c|c|c|c|}
\hline $\begin{array}{l}\text { Hazardous material name } \\
\text { and CAS number }\end{array}$ & Exposure limit ${ }^{\mathrm{a}}$ & $\begin{array}{l}\text { Routes of } \\
\text { exposure }^{b}\end{array}$ & $\begin{array}{l}\text { Symptoms of } \\
\text { overexposure }^{\mathfrak{c}}\end{array}$ & $\begin{array}{c}\text { Target } \\
\text { organs/systems }\end{array}$ & $\begin{array}{l}\text { Carcinogen? } \\
\text { (source) }^{d}\end{array}$ & $\begin{array}{l}\text { Expected } \\
\text { levels }\end{array}$ \\
\hline Aviation hydraulic fluid & 5 ppm (mist) PEL & Ih, Con & $\mathrm{R}, \mathrm{S}$ & skin, resp sys & No & $0 \mathrm{ppm}$ \\
\hline Diesel fumes & $\begin{array}{l}\text { NIOSH Ca } \\
\text { OSHA none }\end{array}$ & Ih, Con & $\mathrm{E}, \mathrm{R}$, [carc] & $\begin{array}{l}\text { Eyes, resp sys, [in } \\
\text { animals: lung } \\
\text { tumors] }\end{array}$ & $\begin{array}{l}\text { potential } \\
\text { occupational }\end{array}$ & $\begin{array}{l}0 \mathrm{ppm} \text { in } \\
\text { observation } \\
\text { area }\end{array}$ \\
\hline
\end{tabular}

a. (PEL) permissible exposure limit; (Ca) potential human carcinogen; (NIOSH) National Institute for Occupational Safety and Health; (OSHA) Occupational Safety and Health Administration.

b. (Ih) inhalation; (Con) skin and/or eye contact.

c. (S) swelling, pain, discoloration; (E) eye tearing; (R) respiratory effects; ([carc]) potential human carcinogen. 


\subsubsection{Industrial Safety Hazards}

Table 2 summarizes the hazards associated with each activity at the task site. Further discussion of these hazards is included in this section.

7.1.4.1 Handling Heavy Objects. Handling and maneuvering of various pieces of heavy equipment may result in personal injury. Manual material handling will be minimized through task design and use of mechanical and hydraulic lifts whenever possible. Personnel may be exposed to injury by lifting heavy objects such as hydraulic hose and metal crane parts. Project members will be trained in the proper methods of lifting heavy objects and cautioned against lifting objects that are too heavy for the individual to handle safely. People involved in manual material handling will wear hand and foot protection as appropriate.

7.1.4.2 Power Tools. All power tools will be properly maintained and used by qualified individuals in a safe manner and in accordance with the manufacturer's recommendations. The LITCO Safety Manual, Section 14, "Hand and Portable Power Tools," will be followed for all work performed with power tools. Employees who use power tools are trained in their use and wear appropriate PPE. Portable electrical tools and equipment have the potential to cause shock or electrocution. Portable electrical tools will be double insulated or ground fault circuit interrupted (GFCI) protected and approved for use if operated in hazardous areas. All equipment and cords will be visually inspected before use. In addition, all portable electrical tools shall be included in the semiannual inspection and testing program. The requirements in the LITCO Safety Manual, Sections 10 and 14, will be followed for all work using portable electrical tools or equipment.

7.1.4.3 Moving Machinery and Falling Objects. While equipment in the EDA is energized, personnel may be subject to cuts and bruises, or involvement with moving machinery. Injuries will be avoided or minimized by following safe practices; while personnel are inside the EDA, the equipment operating speed is limited to $250 \mathrm{~mm} / \mathrm{sec}$ (approx. 10-inches/sec) or less, per ANSI Standard for Robotics Operations (ANSI/RIA R15.06-1992, page 15, Annex A); wearing eye protection and hard hats; and steel-toed footwear and gloves as necessary. Loose clothing or neck chains for security badges will not be worn; long hair must be pulled back and secured when working around equipment with moving parts.

7.1.4.4 Electrical Hazards. Electrical equipment and tools as well as overhead and underground lines may pose shock or electrocution hazards to employees. Safety-related work practices shall be employed to prevent electric shock or other injuries resulting from direct or indirect electrical contact. These practices will conform with the requirements in 29 CFR 1910, Subpart S; 29 CFR 1926, Subpart K; and the LITCO Safety Manual, Section 10. In addition all electrical work will be reviewed and completed under the appropriate work controls. When working on deenergized systems, the requirements in the LITCO Conduct of Operations Manual, Chapter 9, Lockouts and Tagouts, will be followed.

Work on energized systems will be minimized. If work on energized systems is necessary, the requirements in the Lighting and Power Work Matrix, Section 10, Appendix 1, of the LITCO Safety Manual will be strictly enforced. 
Underground utility clearances will be obtained before excavating operations by contacting Telecommunications (526-1688 or 526-2512). The requirements for advanced notice of 48 hours will be met.

7.1.4.5 Heavy Equipment. The hazards associated with the operation of heavy equipment include injury to personnel, equipment damage, and/or property damage. All heavy equipment will be used in the manner in which it was intended. Drivers will have proper training and will operate all equipment in accordance with manufacturers instructions and within the safe operating parameters as defined by the manufacturer. Only required personnel will be allowed in the vicinity of operating heavy equipment and should maintain visual communication with the operator.

7.1.4.6 Elevated Work Areas. When performing certain task site activities (see Table 2), personnel will be required to work on elevated equipment or at heights. When such work is performed, personnel will use a safety belt/harness and lanyard (for work heights exceeding $6 \mathrm{ft}$ ) or a safety net (for work at heights exceeding $25 \mathrm{ft}$ ) per Section 7 of the LITCO Safety Manual. Personnel required to use fall-protection PPE shall be trained in its proper use, limitations, and how to maintain and inspect the equipment.

7.1.4.7 Excavation, Trenching, and Shoring. Excavation work can pose a number of hazards. Specific hazards include: cave-ins, sudden sloughing at pit edges, breech of underground containers, and water accumulation. Work at the task site will involve remote excavations for demonstration purposes of retrieval of containers such as drums or other buried materials. Work in or near any excavation presents serious potential hazards; personnel protective systems, barricades, signs, and daily inspections are some of the safeguards required for excavation work.

7.1.4.8 Inclement Weather. In the event that adverse weather conditions develop that pose a threat to persons or property on the task site, such as sustained strong winds $(25 \mathrm{mph}$ or greater), electrical storms, heavy precipitation, or extreme heat or cold, the situation will be evaluated by the DPM or other personnel, as appropriate. A decision to stop all work at the task site will be made by the DPM (or designee), based on the hazards involved and the situation. Work may proceed provided workers are afforded adequate, appropriate protection. At no time will individual health and safety be jeopardized in order to continue work.

\subsection{Other Task Site Hazards}

Personnel should look for potential hazards and immediately inform the DPM of the hazards so that action can be taken to correct the condition. Each LITCO employee is empowered to immediately stop work if the condition appears to warrant such action.

The PIs, or designated alternate, will conduct, daily inspections of the task site to ensure that barriers and signs are being maintained, unsafe conditions are corrected, and debris is not accumulating on the site. Individuals working at the task site are responsible to use safe work techniques, report unsafe working conditions, and exercise good housekeeping habits. Waste materials will not be allowed to accumulate at the task site. Appropriate containers for waste will be maintained at appropriate locations. Personnel should make every attempt to minimize waste 
through judicious use of consumable materials. All task site personnel are expected to make good housekeeping a priority at the job site.

\section{PERSONAL PROTECTIVE EQUIPMENT}

PPE that will be used at the task site was selected based on the anticipated hazard level. Based on the hazard analysis and the recommendations cited above, a list of the PPE that is required for entry into the EDA follows:

- Hard hat (mandatory)

- Safety eyewear (mandatory)

- $\quad$ Steel-toed footwear (discretionary)

- Hearing protection (discretionary)

- Leather gloves (discretionary)

- Safety harness (discretionary).

Other items may be used depending on the task and hazards involved. Project personnel may seek the advice of the project IH or safety engineer if unsure of PPE requirements.

\section{EMERGENCY RESPONSE PLAN FOR TASK SITE}

The building manager and tenant manager shall ensure that all personnel performing work in the NBA understand and comply with the emergency procedures for Idaho Falls facilities. The nearest emergency response team is the Idaho Falls Fire Department (IFFD), which can be reached at 9-911. The IFFD has response capability for medical emergencies, fires, or hazardous material spills. Building evacuation can be initiated by any personnel by activating the manual pull fire alarm. Emergency response reporting after initial emergency action will be through the following contact: Doris Thompson (526-0157). The DPM is responsible for providing the NBA tenant manager a list of individuals with their phone numbers to contact in the event of an LSFA TRU Arid emergency. Emergency signals and personnel responsibilities at the task site during an emergency event are as provided in Tables 6 and 7, respectively. Emergency eye wash, and spill containment supplies are located in the primary staging area (Figure 2).

Table 6. Emergency signals at building IF-613 (NBA).

\begin{tabular}{lll}
\hline Signal & Indication & Action required \\
\hline $\begin{array}{l}\text { Speaker/light } \\
\text { (bell tone/flashing light) }\end{array}$ & Evacuation & $\begin{array}{l}\text { Secure equipment. Lock } \\
\text { repositories. Immediately } \\
\text { leave building through nearest } \\
\text { exit. }\end{array}$ \\
\hline
\end{tabular}


Table 7. Responsibilities during an emergency.

\begin{tabular}{ll}
\hline \multicolumn{1}{c}{ Responsible person } & \multicolumn{1}{c}{ Action assigned } \\
\hline Any individual may & Signal evacuation, call 911 \\
DPM or alternate & $\begin{array}{l}\text { Call Warning Communication } \\
\text { Center (WCC) 526-1515 }\end{array}$ \\
$\begin{array}{l}\text { Person(s) first aid } \\
\text { certified } \\
\text { DPM or alternate }\end{array}$ & First aid to victims \\
DPM or alternate & $\begin{array}{l}\text { Contact area emergency point } \\
\text { of contact (EPOC) }\end{array}$ \\
Person(s) trained in spill & Contact OMP \\
response & Spill containment \\
DPM or alternate & Spill reporting \\
\hline
\end{tabular}

Spill control at the task site will be handled by task site personnel if the spills are small enough to be safely contained at the site. There are no unknown materials present at IF-613 as part of the LSFA TRU Arid program. Materials present at the Idaho Falls LSFA TRU Arid project that could spill are those used in the fuel, lubrication, and hydraulic systems. If any uncontrolled release of material is noticed, task site personnel shall comply with the following:

\section{Immediate Spill Response Actions}

Initial Responder If you do not know the material's characteristics:

- Leave the area

- Isolate and evacuate the immediate area

- Seek help from and warn others in the area

- Notify PIs and building manager.

Trained Responder If you are trained to respond to the spill:

- $\quad$ Seek help from and warn others in the area

- Stop the spill, if it can be done without risk (e.g., return the container to upright position, close valve, shut off power, etc.)

- Contain the spill as much as possible

- $\quad$ Provide pertinent information to PIs and building manager

- Secure any ventilation paths (if hazardous). 
Emergency Implementing Procedure Number 2 (EIP-2) in the Idaho Falls Buildings Emergency Plan, March 31, 1994, establishes the steps to be taken by the owner of a process or operation at an INEL Idaho Falls building if a hazardous substance is released into the environment. The Environmental Safety and Quality (ES\&Q) Department can assist in determining if the material is a hazardous substance and if the amount spilled is reportable. ES\&Q personnel will also help with necessary spill related notifications. Reportable occurrences should be immediately reported to the tenant manager.

\subsection{Emergency Equipment on the Site}

Emergency response equipment maintained at IF-613 include telephones, manual pull alarms, fire extinguisher, and an automatic sprinkler system. Telephones are available in every office and recommended evacuation routes for IF-613, including fire extinguisher and manual fire alarm locations, are posted in the Primary Staging Area. In addition, PROJECT PERSONNEL must be shown and understand how to operate the emergency shut-off mechanism to the crane, support equipment and all ancillary tools. Other items must be readily available if it is possible that they will be needed.

Emergency drills are conducted annually at Idaho Falls facilities to allow personnel an opportunity to practice their respective emergency response actions. Each drill or actual emergency event is followed by a critique, and any deficiencies in the emergency plan that are identified will be corrected by the emergency response team.

\subsection{Telephone/Radio Contact Reference List for the Cooperative Telerobotic Retrieval System}

Table 8 is list of telephone numbers to call in the event of an emergency or for general project information. The fire and security telephone numbers are attended 24 hours a day. The second part of Table 6 includes a list of key project personnel (bold) available for escorting visitors. Table 6 will be posted at the primary staging area (Figure 2). 
Table 8. Telephone/Radio Contact Reference and Escort List for the Cooperative Telerobotic Retrieval System.

- Warning Communications Center (WCC)

777 or $526-1515$

- Emergency Point of Contact

Doris Thompson

$526-0157$

- Occupational Medical Program (WCB Dispensary)

$526-1596$

- $\quad$ Fire

- Security

$526-0712$

- Safety

Charlie O'Donnell

$526-0722$

- Industrial Hygiene

AEDL ES\&H Coordinator

$526-4113$

- $\quad$ Project Manager

Jim Jessmore

526-7558; pager 5088

- Principal Investigator

Kevin Croft

$526-8276$

- $\quad$ LSFA TRU Arid Deployment Program Manager

Robert Heard

$526-7379$

- $\quad$ LSFA TRU Arid Deployment Coordinator

Larry Watson

$526-2232$

- Key Project Personnel

S. M. Allen

$526-8215$

W. F. Boyer

$525-5591$

L. J. Hanson

$526-4997$

R. A. Hyde

526-0741

S. Walker

526-8815

NOTE: Bolded persons indicated PROJECT PERSONNEL escorts 


\section{REFERENCES}

1. Hyde and Croft, Cooperative Telerobotic Retrieval System Test Plan for Fiscal Year 1994, INEL-94/0035, October 1994. 


\section{Appendix A}

\section{Safety Briefing Training Acknowledgment for CTR Project Areas}




\section{Appendix A}

\section{Safety Briefing Training Acknowledgment for CTR Project Areas}

The signatures below certify that:

- The person has reviewed a copy of the safety plan for the EDA and questions and concerns regarding tasks and associated hazards have been answered.

- The person understands the hazards that are or may be involved in the EDA.

- The person agrees to comply with all requirements as outlined in this safety plan.

- The person's training records have been verified as complete and current.

- Person understands and accepts his/her responsibilities for escorting non-project personnel into designated areas.

Employee's name (printed) and signature:

Print Signature Date

Company of employment:

PIs approval name (printed) and signature:

Print

Signature

Date 